\title{
A José Amarante Santos Sobrinho
}

Cristóvão José dos Santos Júnior ${ }^{1}$

Recebido em: 11 mar. 2020

Aceito em: 30 jul.2020

DOI 10.26512/aguaviva.v5i3.29916

Assiduamente o educador de ideias

Manifesta seus lumes ressonantes,

Acolhendo, no ensino, os estudantes

Renascidos em sábias Panaceias.

Aos ataques fascistas de plateias

Necrosadas por jingles delirantes

Traz Fulgêncios e Ausônios, e ainda Dantes,

E Ilíadas, e Eneidas, e Odisseias!

Suas palavras reavivam seus alunos

A sua escrita elucida e reconstrói,

Não cedendo ante os sons inoportunos...

Tem Amarante o sopro da vitória.

Orfeu da Educação, é o nosso herói,

Semeando a paz em larga trajetória!...

\footnotetext{
${ }^{1}$ Doutorando em Literatura e Cultura e mestre em Literatura e Cultura (2019) pela Universidade Federal da Bahia (UFBA). Graduado em Direito (2017) e graduando em Letras Clássicas (Latim e Grego Antigo) pela Universidade Federal da Bahia. E-mail: cristovao_jsib@ hotmail.com
} 